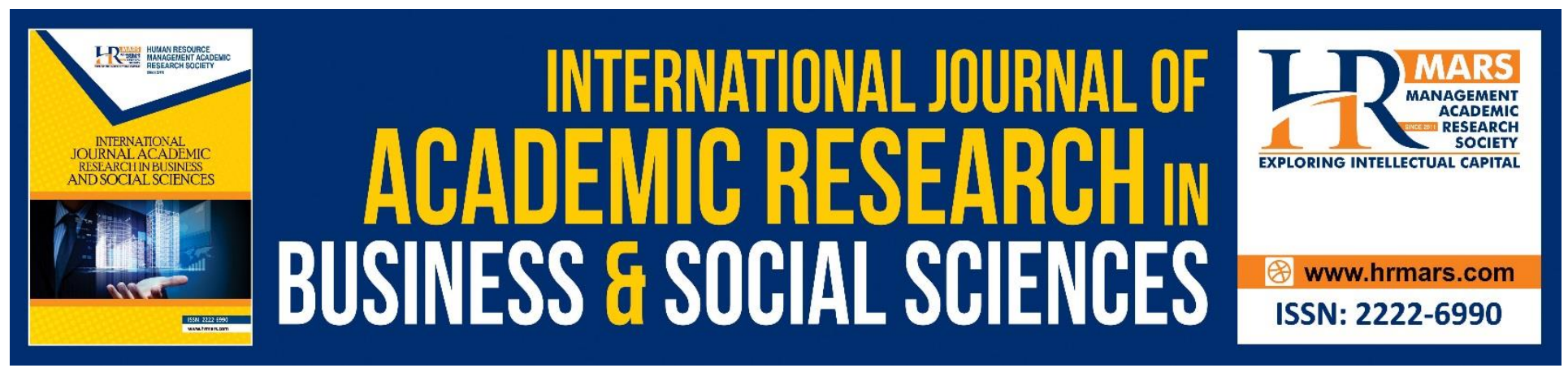

\title{
The Effects of Human Capital, Financial Socialisation Agents, and Motivation on Financial Literacy Among Private University Students In Malaysia
}

Hafizah Mat Nawi, Ong Hock Siong, Chen Yuen Nee

To Link this Article: http://dx.doi.org/10.6007/IJARBSS/v10-i10/7737

DOI:10.6007/IJARBSS/v10-i10/7737

Received: 08 August 2020, Revised: 27 August 2020, Accepted: 19 September 2020

Published Online: 15 October 2020

In-Text Citation: (Nawi, Siong, \& Nee, 2020)

To Cite this Article: Nawi, H. M., Siong, O. H., \& Nee, C. Y. (2020). The Effects of Human Capital, Financial Socialisation Agents, and Motivation on Financial Literacy Among Private University Students In Malaysia. International Journal of Academic Research in Business and Social Sciences. 10(10), 159-168.

Copyright: (C) 2020 The Author(s)

Published by Human Resource Management Academic Research Society (www.hrmars.com)

This article is published under the Creative Commons Attribution (CC BY 4.0) license. Anyone may reproduce, distribute, translate and create derivative works of this article (for both commercial and non-commercial purposes), subject to full attribution to the original publication and authors. The full terms of this license may be seen

at: http://creativecommons.org/licences/by/4.0/legalcode

Vol. 10, No. 10, 2020, Pg. 159 - 168

http://hrmars.com/index.php/pages/detail/IJARBSS

JOURNAL HOMEPAGE

Full Terms \& Conditions of access and use can be found at http://hrmars.com/index.php/pages/detail/publication-ethics 


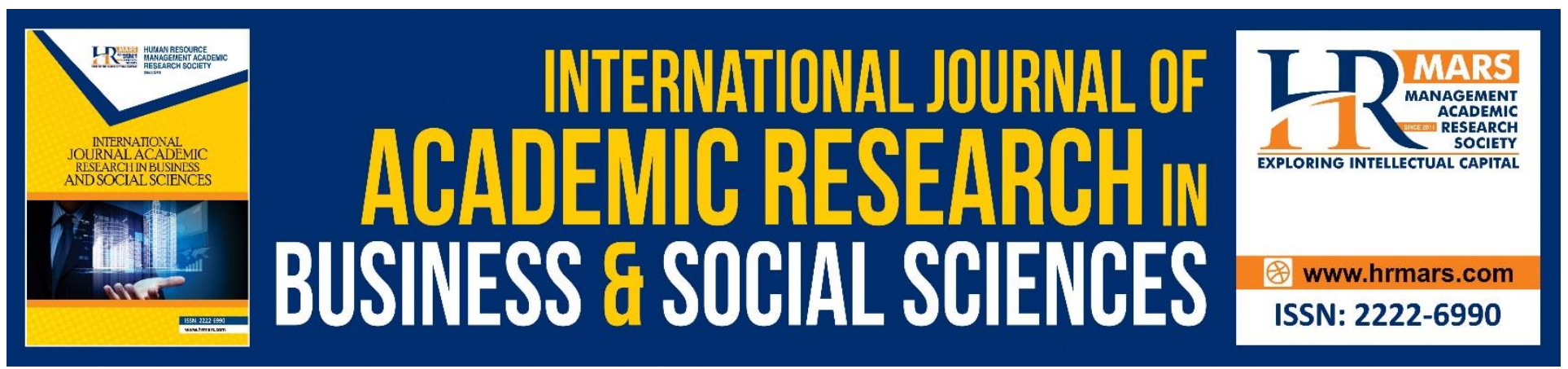

\title{
The Effects of Human Capital, Financial Socialisation Agents, and Motivation on Financial Literacy Among Private University Students In Malaysia
}

\author{
Hafizah Mat Nawi ${ }^{1}$, Ong Hock Siong ${ }^{2}$, Chen Yuen $\mathrm{Nee}^{3}$ \\ ${ }^{1}$ Faculty of Management and Defence Studies, National Defence University of Malaysia, Kuala \\ Lumpur, ${ }^{2 \& 3}$ Faculty of Business \& Management, Quest International University, Perak \\ Email: hafizah.matnawi@upnm.edu.my
}

\begin{abstract}
The ability to manage personal finances has become increasingly significant, particularly for university students. This study has examined the influence of human capital, financial socialisation agents and motivation on financial literacy among private university students in Malaysia. A survey consisted of 390 students was conducted from various private universities based on positive paradigm approach. The survey data collected was then analysed using statistical techniques and multiple regression models. The survey results showed that human capital, financial socialisation agents and motivation have significant effects on individuals financial literacy and supported the theory of planned behaviour. The research findings provide insights for policymakers to improve financial literacy among students in higher education institutions. Policymakers such as the Malaysian government and the Ministry of Higher Education can utilise the findings for the National Strategy for Financial Literacy 2019-2023 and the Malaysia Education Blueprint 2015-2025.
\end{abstract}

Keywords: Financial Literacy, Financial Socialisation Agents, Malaysia Education Blueprint 20152025, Motivation, Private University.

\section{Introduction}

Majority of students usually experience financial responsibilities when they attend universities or colleges to further their tertiary education which indicates a crucial time in their lives as they transition from financial dependence to financial independence. In terms of financial literacy, most students demonstrated a low level of financial literacy despite having more money to spend (Henry et al., 2001). Their spending behaviour is often influenced by the financial knowledge and practices that they acquired before their tertiary education placement. This case is further supported by several studies that concluded almost half of the students showed a severe deficiency in their understanding of everyday financial matters (Albeerdy \& Gharleghi, 2015).

Despite the significance of financial literacy, many studies worldwide indicated that a high number of the world's population still suffers from financial illiteracy thus effective measures and 
INTERNATIONAL JOURNAL OF ACADEMIC RESEARCH IN BUSINESS AND SOCIAL SCIENCES Vol. 10, No. 10, 2020, E-ISSN: 2222-6990 @ 2020 HRMARS

viable solutions are required to remedy the problem (Thaler, 2013). The financial illiteracy could lead to financial issues (Yew et al., 2017) which may indirectly cause unsustainable economic growth in the countries (Lombardi et al., 2017). Hence, improving the financial literacy among students in higher education institutions is crucial because they represent the younger population which will eventually benefit from financial planning and savings in their later years.

Similarly, in Malaysia, the lack of financial literacy and savings might hinder or impede the country's progress to become one of the top 20 nations in the world by 2050 (National Transformation, 2050). Currently, the government has taken various initiatives to improve financial literacy among nations however, the level of bankruptcy still increases (Department of Insolvency, 2019). Thus, financial literacy knowledge is crucial in shaping better citizens who will contribute to the nation's development. In addition, a study by Yoshino et al. (2015, cited by Nawi \& Hussin, 2020) stressed on the scarcity of research on the topic by affirming that "financial education provision remains under the academic and policy radar in Asia" (p. 275).

Studies on individual's financial literacy are still in the early stage of development with only a few studies on the differences in socioeconomic and demographic variables (Idris et al., 2016). Thus, this study seeks to advance the understanding of individual's financial literacy using a multidimensional construct to analyse financial literacy, which simultaneously covers the sociodemographic, human capital, financial socialisation agents and motivation, as suggested by previous researchers (Lusardi \& Mitchell, 2007; Mandell \& Klein, 2007; Nicolini, Cude \& Chatterjee, 2013; OECD, 2013). Therefore, this study examines the factors influencing financial literacy among students in Malaysian private universities.

\section{Literature Review: Theoretical and Empirical}

Financial literacy refers to an individual's knowledge about principles, concepts, and technological tools that are related to finances or money for short, medium or long term periods (Tavares et al., 2019). The earliest definition of financial literacy by Noctor, Stoney and Stradling (1992) defined it as "the ability to make informed judgments and take effective decisions regarding the use and management of money" (p.4). Meanwhile, the Commonwealth Bank Foundation-CBF (2004) refers to financial literacy as "the ability to balance a bank account, prepare budgets, save for the future and learn strategies to manage or avoid debt" (p.1).

Financial literacy benefits every individual as it helps for better funds management and having sufficient funds to support their daily life (Nawi et al., 2020). Mustapha and Jeyaram (2015) asserted that a high level of financial literacy is essential for current students because of today's complex marketplace. Students should have a level of financial literacy to understand the budgeting, savings, credit cards, investment activities and many other financial tools and concepts.

Besides, financial literacy enables individuals to organise and handle commercial information and make decisions about financial planning, wealth accumulation, debt, and pensions with full knowledge of the possible risks and benefits (Nawi et al., 2020). Hence, financial literacy is useful for students in making sound short and long-term financial decisions. In contrast, financial illiteracy can lead to financial problems that may lead to mental illness, stress, lower self-esteem and misery. This case is further supported based on the Organisation for Economic Co-operation and Development (2013) definition of financial literacy as a mix of knowledge, consciousness, talent, attitude, and conduct which are essential to produce financial decisions to ensure a person's financial happiness and security. The study used three test-based measures, which relied on questions in the study of 
INTERNATIONAL JOURNAL OF ACADEMIC RESEARCH IN BUSINESS AND SOCIAL SCIENCES

Vol. 10, No. 10, 2020, E-ISSN: 2222-6990 @ 2020 HRMARS

Lusardi and Tufano (2009) to measure debt literacy. The questions are related to financial literacy specifically concerned with focusing on the cost of credit.

\section{Theories}

This study tested two theories, namely, life-cycle theory and the theory of planned behaviour (TPB). The life-cycle theory was proposed by Penrose (1952, cited by Mat Nawi, 2015) that focuses on the development of an individual's consumption and savings behaviours. The theory was further developed by Modigliani and Brumberg (1954), who introduced the life-cycle model of asset allocation and accumulation. The model differentiates between the propensity to consume and save at various stages of an individual's life. The theory predicts that consumption and savings behaviours change significantly with objective (i.e. income, rates of returns, wealth) and subjective factors (i.e. age, marital status, socioeconomic and demographic conditions) during various stages of the individual's life.

Alternatively, the TPB was developed by Fishbein and Ajzen (1975). The TPB emphasises that an individual's behaviour arises due to their intentions to behave. In other words, individual's will act based on their belief of what is most appropriate with considerations of the three factors that determine human actions, namely behavioural belief, normative belief, and control belief.

\section{Financial Literacy and Human Capital}

Human capital is defined as a combination of knowledge and skills possessed by an individual obtained through formal or informal education (Mat Nawi, 2015). A study by Lee \& Lown (2012) found that students with financial education had higher positive savings scores as compared to those without financial education. Besides, students who received financial education in primary schools had a higher level of savings attitude as compared to those who received financial education later in college (Lee \& Lown, 2012). This case is further supported by Lusardi and Mitchell (2014) stated that individuals with a higher level of education would likely have a higher level of financial literacy.

Similarly, Nano and Cani (2013) asserted that most university students without personal financial education had a low level of financial literacy. The study of Nano and Cani (2013) proved that students with any form of financial management course were more literate than students without the course. Likewise, Douissa (2019) stated that having a high level of formal education could increase the level of financial literacy as people tend to be more responsible for their financial behaviour. However, Tavares et al. (2019) argued that students, regardless of their field of study, would have a low level of financial literacy due to lack of discipline in managing their accounts.

Regardless of the inconsistent findings on the association between human capital and financial literacy, it can be concluded that the importance of formal financial literacy education necessitates the existence of many financial aid professionals to educate students. Accordingly, the following hypothesis is proposed:

Hypothesis $1(\mathrm{H} 1)$ : There is a positive association between human capital and financial literacy.

\section{Financial Literacy and Financial Socialisation Agents}

Financial socialisation refers to a process of an individual acquiring knowledge, skills and attitudes from the environment (Sohn et al., 2012). The knowledge acquisition aims to maximise the individual's consumer role in the financial market. Financial socialisation agents comprise of family, 
INTERNATIONAL JOURNAL OF ACADEMIC RESEARCH IN BUSINESS AND SOCIAL SCIENCES Vol. 10, No. 10, 2020, E-ISSN: 2222-6990 @ 2020 HRMARS

peers and media that work independently and differently throughout the life-cycle (Kim \& Chatterjee, 2013).

Albeerdy and Gharleghi (2015) argued that the family's attitude influences an individual's spending or consumption behaviour in expenditures. The individual is naturally inclined to follow their parents' method of managing and spending money because they were raised to behave in the same culture that uses the same principles (Albeerdy \& Gharleghi, 2015; Mandell \& Klein, 2009).

In contrast, Sohn et al. (2012) stated that parental influence weakens over time as peer influence grows because of the individual's exposure to numerous socialisation agents as they mature (Robertson-Rose, 2019). The individual will learn about consumer roles through interactions with these financial socialisation agents (Douissa, 2019). Previous studies have also shown the influence of media on the individual's financial literacy (Sohn et al., 2012). To further support this association, Kim and Chatterjee (2013) found a positive relationship between the degree of media usage as an information source for finance and financial practices. The above discussion suggests the following hypothesis:

Hypothesis $2(\mathrm{H} 2)$ : There is a positive association between financial socialisation agents and financial literacy.

\section{Financial Literacy and Motivation}

Filipovic and Popovic (2019) categorised motivation into extrinsic and intrinsic. The extrinsic motivation relates to external parties such as rewards, money, praise and grades. Contrarily, the intrinsic motivation originates from individuals themselves, such as their initiatives to do something for their own sake. Concerning literacy, the association between literacy and motivation was shown in the competence motivation theory by Harter (1981). Harter (1981) asserted that perceived competence is intrinsically related to intrinsic motivation.

Besides, the force model of Vroom (1964) and the utility model of Samuelson (1967) proved the motivational influence on human behaviour. These theories emphasise that individuals are motivated by things that can lead to valued outcomes with a focus on functions of expectancy, instrumentality, and valence or utility. This association is further supported by Locke and Latham (1990) with motivation and the goal-setting theory. They asserted that the chance of success for financial literacy courses would be higher if individuals were positively motivated by perceptions and awareness concerning financial stability in their life. Similarly, Nguyen et al. (2019) found that methods using motivation and knowledge were useful in assisting students in stock market investment as most students were risk-averse. Mandell and Klein (2007) also proved a positive association between motivation and financial literacy. The above discussion suggests the following hypothesis:

Hypothesis $3(\mathrm{H} 3)$ : There is a positive association between motivation and financial literacy. 
INTERNATIONAL JOURNAL OF ACADEMIC RESEARCH IN BUSINESS AND SOCIAL SCIENCES Vol. 10, No. 10, 2020, E-ISSN: 2222-6990 @ 2020 HRMARS

The hypotheses from the literature review are conceptualised in the following model:

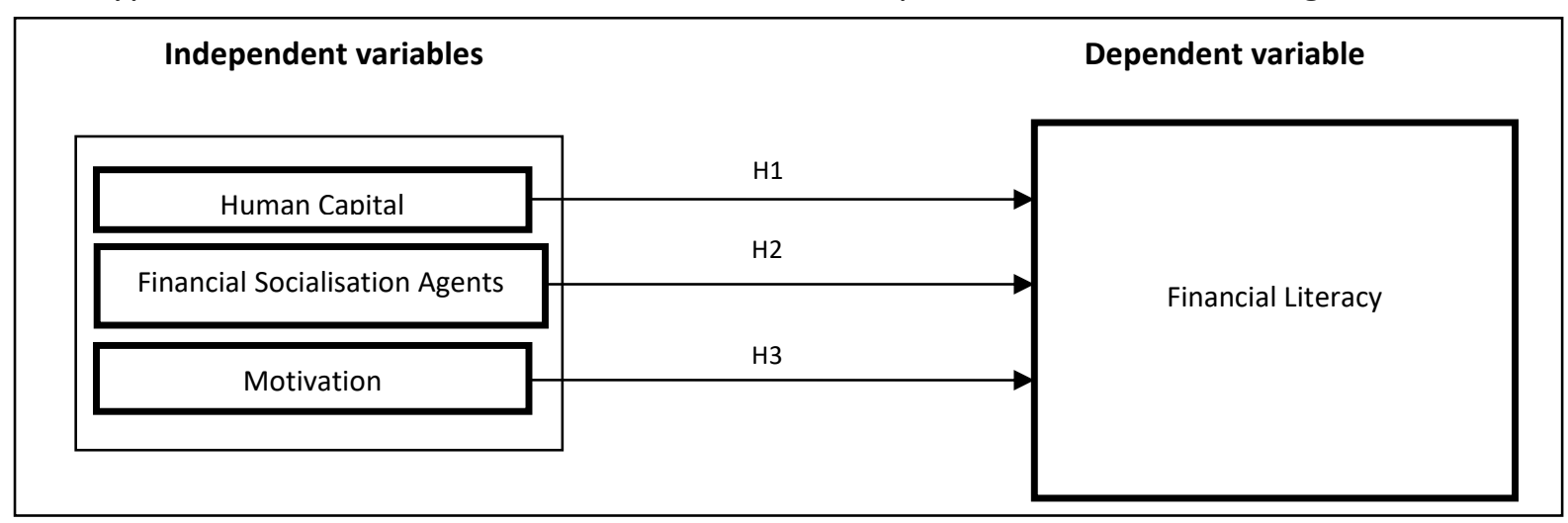

\section{Methodology}

A survey questionnaire was conducted among undergraduate and post-graduate students in private universities in the Northern Corridor Economic Region (NCER) of Malaysia. The study received 390 usable responses with a response rate of 77 per cent. The number of samples received achieved the minimum number of sample size for generalisation. The researchers personally administered the survey questionnaire to avoid non-response issues. All accessible students were chosen as subjects.

The survey questionnaire was developed by adopting and adapting questions from previous research such as Nicolini et al. (2013) and Lusardi and Mitchell (2007) with considerations on their suitability with the context, population and objectives of the study. The researchers designed the questionnaire in several stages. Firstly, the researchers identified the knowledge and skills needed for a student to be considered financially literate by consulting experts and academics finance and accounting fields. Then, the financial literacy questions were developed based on four areas, namely investment, credit/mortgage, inflation and money management. The survey questionnaire also included students' sociodemographic details, socioeconomic details and prior participation in courses related to economics and finance.

In terms of analysis, a pilot test was undertaken before the main survey to ensure no issues of reliability and for questionnaire clarification. Amendments were made to improve the meaning and flow of the questionnaire. The survey data were then analysed with descriptive and multiple regression analysis.

\section{Results}

The descriptive statistics presented the demographic information of the respondents comprised of 62.5 per cent of females and 37.5 per cent of males currently enrolled across six programmes. The majority of respondents were from business programme ( 37.5 per cent) and the lowest was from the engineering programme ( 7.0 per cent). In terms of the respondents' education level, 47.0 per cent were bachelor's degree students, less than 25.0 per cent were post-graduate students, and the remaining students were diplomas and certificates students. The statistics also presented the descriptive information on the level of understanding of financial literacy, which focused on investment, credit/mortgage, inflation and money management. Results revealed that less than 46.0 per cent of the respondents scored a high level of understanding for all four areas.

Further, this study analysed the reliability of each variable and its internal consistency using the reliability analysis for both the pilot and the main study. The items were retained as the Cronbach 
INTERNATIONAL JOURNAL OF ACADEMIC RESEARCH IN BUSINESS AND SOCIAL SCIENCES Vol. 10, No. 10, 2020, E-ISSN: 2222-6990 @ 2020 HRMARS

alpha for all independent variables were above 0.70 , which indicated high reliability. For internal consistency, this study reaffirmed the reliability of each factor by considering the 'Item-Total Correlations' and 'Alpha if Item Deleted'. The internal consistency results were all substantial at 0.001 levels with the 'Item-Total Correlations' were satisfactory above the threshold value 0.35 . This study also generated a 2-tailed Pearson correlation matrix for each set of predictor variables. The results indicated that the strength of the associations between financial literacy and each independent variable was moderate as the correlation values fall under the range of 0.40 to 0.59 . The significance of the relationship between variables was less than alpha value 0.01 .

The associations between independent variables and dependent variable were analysed using a Multiple Regression Analysis. The analysis tested the three hypotheses $(\mathrm{H} 1, \mathrm{H} 2$ and $\mathrm{H} 3)$. The model summary (Table 1) indicates that approximately 62.4 per cent of the variations in financial literacy (the coefficient of determination - R square) was explained by the independent variables (i.e. human capital, financial socialisation agents and motivation). Less than one-third of the variations were explained by other independent variables that were not included in this research.

The table also shows that motivation was the most significant factor influencing financial literacy $(\beta=0.632, p=0.000)$. The model indicates that every one unit increase in the motivation, the predicted dependent variable (i.e. financial literacy) increases by 63.2 percent. This result supported the findings of Mandell and Klein (2007) and Nawi and Hussin (2020) on the positive association between motivation and financial literacy. Similar patterns were found in the associations between the other two independent variables and financial literacy, namely financial socialisation agents and human capital $(\beta=0.448, p=0.000$ and $\beta=0.350, p=0.000)$. The model indicates that every one unit increase in financial socialisation agents and human capital, the predicted dependent variable (i.e. financial literacy) increases by 44.8 percent and 35 percent, respectively. The overall results supported the theory of planned behaviour. Thus, this study accepted all H1, H2 and H3 as all associations significantly relate to the dependent variable.

Table 1: Results of Multiple Regression Analysis

\begin{tabular}{|c|c|c|c|c|c|c|c|c|c|}
\hline \multicolumn{10}{|c|}{ Model Summary } \\
\hline \multicolumn{2}{|c|}{$\begin{array}{l}\text { Mode } \\
\text { | }\end{array}$} & $\mathrm{R}$ & $\begin{array}{l}\text { R } \\
\text { Squ }\end{array}$ & & Adjusted & dare & Std. & or of th & stimate \\
\hline \multicolumn{2}{|l|}{1} & $.722 a$ & \multicolumn{2}{|c|}{.624} & \multicolumn{2}{|l|}{.611} & \multicolumn{3}{|c|}{.78633} \\
\hline \multicolumn{10}{|c|}{ a. Predictors: (Constant), Morale, Compliance, Knowledge } \\
\hline \multicolumn{10}{|c|}{ Coefficients - a. } \\
\hline \multirow{2}{*}{\multicolumn{3}{|c|}{ Model }} & \multicolumn{3}{|c|}{$\begin{array}{c}\text { Unstandardised } \\
\text { Coefficients }\end{array}$} & \multicolumn{2}{|c|}{ Standardised Coefficients } & \multirow[t]{2}{*}{$\mathrm{t}$} & \multirow[t]{2}{*}{ Sig. } \\
\hline & & & $\mathrm{B}$ & & Std. Error & Beta & & & \\
\hline \multirow[t]{4}{*}{1} & \multicolumn{2}{|c|}{ Constant } & .159 & .29 & & & & .459 & .619 \\
\hline & \multicolumn{2}{|l|}{$\mathrm{HC}$} & .350 & .07 & & .297 & & 4.054 & .000 \\
\hline & \multicolumn{2}{|l|}{ FSA } & .448 & .09 & & .436 & & 4.402 & .000 \\
\hline & \multicolumn{2}{|c|}{ Mot } & .632 & .09 & & .491 & & 6.555 & .000 \\
\hline \multicolumn{10}{|c|}{ a. Dependent Variable: Financial Literacy } \\
\hline \multicolumn{10}{|c|}{ Note: HC= Human Capital; FSA= Financial Socialisation Agents; Mot= Motivation } \\
\hline
\end{tabular}


INTERNATIONAL JOURNAL OF ACADEMIC RESEARCH IN BUSINESS AND SOCIAL SCIENCES Vol. 10, No. 10, 2020, E-ISSN: 2222-6990 @ 2020 HRMARS

\section{Discussion and Conclusion}

The results showed all tested independent variables were found to be significantly associated with the financial literacy among private university students in Malaysia. Motivation was found to be the most influential factor, followed by financial socialisation agents and human capital. In line with the findings of Nguyen et al. (2019), findings showed that most students possess high financial literacy due to their own perceptions and self-motivation. Moreover, findings indicate that private university students were mostly influenced by family's attitude as majority of them are self-sponsored and their monetary allowances were supported by their parents. At the same time, their relationship with friends and exposure to the media also contribute significantly to their financial literacy. In addition, students' knowledge and skills contributes up to one-third of the overall results. The findings identified that financial programmes aimed at achieving adequate financial literacy should consider the incorporation of financial planning and knowledge-related activities. The study also demonstrated that a lack of financial literacy and poor financial management among students could lead to irresponsible spending and other problems relating to academic performance, mental and physical well-being, and employment after graduation.

The research makes several significant contributions to existing studies on financial literacy such as identifying the importance of providing students with adequate knowledge of investment, credit/mortgage, inflation and money management. Other than the students themselves, parents should also improve or strengthen their financial knowledge. This initiative will indirectly increase the level of financial literacy among their children. Furthermore, the findings are also useful for policymakers in formulating policies on financial management and financial planning. For instance, the government should adopt effective financial literacy strategies to avoid and solve financial problems among the students in higher education institutions as it is crucial for the future and wellbeing of individuals (CBF, 2004). Policymakers such as the Malaysian government and the Ministry of Higher Education can utilise the findings to achieve the National Strategy for Financial Literacy 20192023 and the Malaysia Education Blueprint 2015-2025.

The limitation of this study presents opportunities for future research. As the sample was solely based on private universities in the country, it may not be sufficient to generalise the findings to the entire population of the students in the Malaysian of higher education institutions. Future research may also consider a comparative study on the same topic among Generation X, Y, and baby boomers. Further, research related to personal finance in Malaysia may want to consider the role of media as an external influence on the financial knowledge and behaviours of the students of higher education institutions.

\section{References}

Albeerdy, M. I., \& Gharleghi, B. (2015). Determinants of the financial literacy among college students in Malaysia. International Journal of Business Administration, 6(3).

Calamato, M. P. (2010). Learning financial literacy in the family, San Jose State University.

Commonwealth Bank Foundation (CBF). (2004). Improving Financial Literacy in Australia: Benefits for the Individual and the Nation, Research Report. Commonwealth Bank Foundation, Sydney.

Department of Insolvency. (2019). Bankruptcy Statistics December 2018. Retrieved: December 28, 2019, from: http://www.mdi.gov.my/index.php/about-

us/resources/statistics/bankruptcy/1390- 
INTERNATIONAL JOURNAL OF ACADEMIC RESEARCH IN BUSINESS AND SOCIAL SCIENCES

Vol. 10, No. 10, 2020, E-ISSN: 2222-6990 @ 2020 HRMARS

Douissa, I. B. (2019). Factors Affecting College Students' Multidimensional Financial Literacy in the Middle East. International Review of Economics Education, 100173.

Filipovic, J., \& Popovic, A. (2019). How to recognize potential school leaders among primary school teachers: Framework based on financial literacy level and type of motivation. Management: Journal of Contemporary Management Issues, 24(Special Issue), 107-121.

Fishbein, M., \& Ajzen, I. (1977). Belief, attitude, intention, and behavior: An introduction to theory and research.

Furnham, A., Von Stumm, S., \& Fenton-O'Creevy, M. (2015). Sex differences in money pathology in the general population. Social Indicators Research, 123(3), 701-711.

Harter, S. (1981). A new self-report scale of intrinsic versus extrinsic orientation in the classroom: Motivational and informational components. Developmental Psychology, 17, 300-312.

Henry, R. A., Weber, J. G., \& Yarbrough, D. (2001). Money management practices of college students. College Student Journal, 35(2), 244-244.

Idris, N. H., Yazid, Z. A., Faique, F. A., Daud, S., Ismail, S., Bakri, M. H., \& Taib, N. M. (2016). Financial literacy and debt burden among Malay youth workers in Malaysia. Advanced Science Letters, 22(12), 4288-4292.

Kim, J., \& Chatterjee, S. (2013). Childhood financial socialization and young adults' financial management. Journal of Financial Counseling and Planning, 24(1), 61.

Lee, Y. G., \& Lown, J. M. (2012). Effects of Financial Education and Impulsive Buying on Saving Behavior of Korean College Students. International Journal of Human Ecology, 13(1), 159-169.

Locke, E. A., \& Latham, G. P. (1990). A Theory of Goal Setting and Task Performance. Englewood Cliffs, NJ: Prentice-Hall, Inc.

Lombardi, M., Mohanty, M.S., \& Shim, I. (2017). The real effects of household debt in the short and long run. BIS Working Paper No. 607. Retrieved: December 24, 2019, from: https://papers. ssrn.com/sol3/papers.cfm?abstract_id=2906555...

Lusardi, A., \& Mitchell, O. S. (2007). Financial literacy and retirement planning: New evidence from the Rand American Life Panel. Michigan Retirement Research Center Research Paper No. WP, 157.

Lusardi, A., \& Mitchell, O. S. (2014). The economic importance of financial literacy: Theory and evidence. Journal of Economic Literature, 52(1), 5-44

Lusardi, A., \& Tufano, P. (2009). Teach workers about the perils of debt. Harvard Business Review, 87(11), 22-24.

Mandell, L., \& Klein, L. S. (2007). Motivation and financial literacy. Financial services review, 16(2), 105

Mandell, L., \& Klein, L. S. (2009). The impact of financial literacy education on subsequent financial behavior. Journal of Financial Counseling and Planning, 20(1).

Malaysia Education Blueprint 2015-2025. Retrieved: Jan 20, 2020, from http://www.moe.gov.my/.

Mat Nawi, H. (2015). Determinants of capital structure in small and medium sized enterprises in Malaysia (Doctoral dissertation, Brunel University London).

Modigliani, F., \& Brumberg, R. (1954). Utility analysis and the consumption function: An interpretation of cross-section data. Post-keynesian economics, 1, 338-436

Mustapha, M., \& Jeyaram, S. (2015). Financial literacy and demographic factors. Journal of Technology Management and Business, 2(1). 
INTERNATIONAL JOURNAL OF ACADEMIC RESEARCH IN BUSINESS AND SOCIAL SCIENCES Vol. 10, No. 10, 2020, E-ISSN: 2222-6990 @ 2020 HRMARS

Nano, D., \& Cani, S. (2013). The Differences in Students' Financial Literacy based on Financial Education. Academics. International Scientific Journal, 2013(8), 149-160.

Nguyen, P. S., \& Becerra, B. J. (2019). Motivation, knowledge, and confidence in stock market investing among a diverse college student population. Retrieved: December 24, 2019, from https://www.sccur.org/sccur/fall_2019_conference/oral_session_1/65/

Nicolini, G., Cude, B. J., \& Chatterjee, S. (2013). Financial literacy: A comparative study across four countries. International Journal of Consumer Studies, 37(6), 689-705.

Noctor, M., Stoney, S., \& Stradling, R. (1992). Financial literacy: a discussion of concepts and competences of financial literacy and opportunities for its introduction into young people's learning. National Foundation for Educational Research.

Organisation for Economic Co-Operation and Development. Financial literacy and inclusion: Results of OECD/INFE survey across countries and by gender. OECD Publishing. 2013. Retrieved: January 20, 2018, from:

http://www.oecd.org/daf/fin/financialeducation/TrustFund2013_OECD_INFE_Fin_Lit_and_I ncl_SurveyResults_by_Country_and_Gender.pdf >

Robertson-Rose, L. (2019). "Because My Father Told Me To": Exploratory Insights into Parental Influence on the Retirement Savings Behavior of Adult Children. Journal of Family and Economic Issues, 1-13.

Samuelson, P. (1967). Economics. New York: McGraw-Hill Book Co.

Sohn, S. H., Joo, S. H., Grable, J. E., Lee, S., \& Kim, M. (2012). Adolescents' financial literacy: The role of financial socialization agents, financial experiences, and money attitudes in shaping financial literacy among South Korean youth. Journal of adolescence, 35(4), 969-980.

Tavares, F. O., Almeida, L. G., \& Cunha, M. N. (2019). Financial Literacy: Study of a University Students Sample. International Journal of Environmental and Science Education, 14(9), 499-510.

Thaler, R. H. (2013). Financial literacy, beyond the classroom. The New York Times.

Vroom, V. H. (1964). Work and Motivation. New York: John Wiley \& Sons.

Yew, S. Y., Yong, C. C., Cheong, K. C., \& Tey, N. P. (2017). Does financial education matter? education literacy among undergraduates in Malaysia. Institutions and Economies, 43-60. 